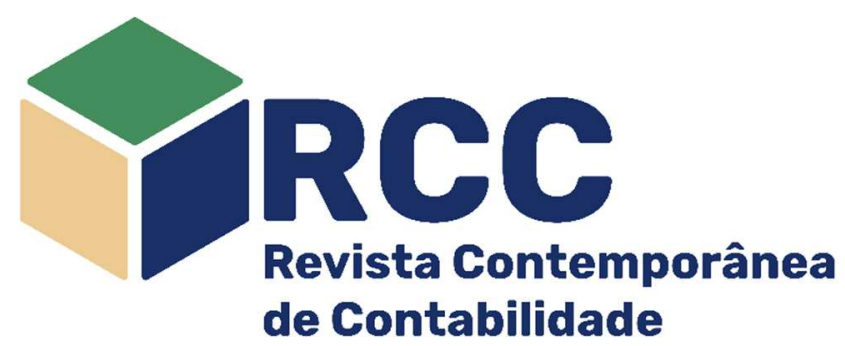

\title{
Papel do Tribunal de Contas no controle financeiro municipal
}

\author{
Role of the Audit Court in municipal financial control
}

\section{Función de la Corte de Auditoría en el control financiero municipal}

\author{
Wesley de Almeida Mendes* \\ Mestre em Administração (UFV), Doutorando em \\ Administração (UFV), Viçosa/MG, Brasil \\ wesleytstcerest@gmail.com \\ https://orcid.org/0000-0001-6443-2572 (0)
}

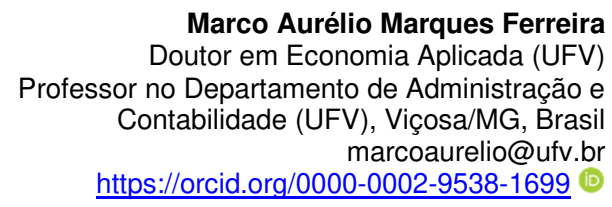

Marco Aurélio Marques Ferreira

omia Aplicada (UFV)

marcoaurelio@ufv.br

\author{
Lucas de Paula Rocha \\ Graduado em Ciências Contábeis (UFV), Viçosa/MG, Brasil \\ Email: lucaasLPR@gmail.com \\ ORCID: https://orcid.org/0000-0001-6623-7404 (10)
}

Evandro Rodrigues de Faria

Doutor em Administração (UFMG)

Professor no Departamento de Administração e

Contabilidade (UFV), Viçosa/MG, Brasil

evandroadm@ufv.br

https://orcid.org/0000-0001-7982-3947 (1)

Endereço do contato principal para correspondência* Av. Peter Henry Rolfs, s. n., Campus Universitário, CEP: 36570-000 - Viçosa/MG Brasil

\begin{abstract}
Resumo
Apesar dos avanços que a Lei de Responsabilidade Fiscal apresentou para a gestão fiscal, ainda são descumpridas as normas estabelecidas, assim, o presente estudo visou verificar os julgamentos das contas de governo dos municípios de Minas Gerais. Por meio da pesquisa documental, foram analisados os relatórios de contas de governo, referentes ao ano de 2015, de 684 municípios mineiros, que foram divididos conforme a condição de aprovação e reprovação e, em seguida, foram verificadas as descrições das prestações de contas dos municípios. Os resultados indicaram que o principal motivador de rejeição das contas foi o não cumprimento dos limites constitucionais de gastos com saúde e educação. Notou-se ainda que, apesar de os pareceres do TCEMG configurarem decisões sobre as contas públicas, seus pareceres não possuem efeitos imediatos, visto que as decisões são deliberadas no plenário das câmaras municipais.
\end{abstract}

Palavras-chave: Accountability; Administração Pública; Tribunal de Contas

\begin{abstract}
In spite of the advances that the Law of Fiscal Responsibility presented for the fiscal management, the norms established are still not complied with. The study aimed at verifying the judgments of the government accounts of the municipalities of Minas Gerais. Through the documentary research, the reports of government accounts for the 2015 fiscal year in 684 municipalities of Minas Gerais were analysed. We divide the reports based on the condition of approval or disapproval and then we examine the descriptions of the account's renderings. The results pointed the main factors for rejecting the accounts were for failure to comply with the constitutional limits of health and education. We noted that, despite the report of the TCEMG, they do not have immediate effects on the manager, the decisions of which are deliberated in the plenary of the municipal councils.
\end{abstract}

Keywords: Accountability; Public Administration; Audit Court

\section{Resumen}

A pesar de los avances que la Ley de Responsabilidad Fiscal presentó para la gestión fiscal, las normas establecidas aún no se cumplen. El objetivo del estudio fue verificar los juicios de las cuentas del gobierno de los municipios de Minas Gerais. A través de la investigación documental, se analizaron los informes de cuentas gubernamentales para el año fiscal 2015 en 684 municipios de Minas Gerais. Dividimos los informes según la condición de aprobación o desaprobación y luego examinamos las descripciones de los rendimientos de las cuentas. Los resultados apuntaron que los principales factores para rechazar las cuentas fueron el incumplimiento de los límites constitucionales de salud y educación. Notamos que, a pesar del informe del 
TCEMG, no tienen efectos inmediatos en el gerente, cuyas decisiones se deliberan en la plenaria de los consejos municipales.

Palabras clave: Responsabilidad; Administración pública; Tribunal de Cuentas

\section{Introdução}

A crescente demanda por serviços públicos e a escassez de recursos por parte da gestão impõem aos órgãos públicos maior cuidado para realizar políticas e aplicar recursos. A saúde fiscal, nesse sentido, trata-se de um elemento importante dentro das ações da gestão pública, uma vez que consiste na capacidade de arrecadar e aplicar recursos de forma a não comprometer o bom funcionamento da máquina pública, sem afetar a capacidade de atender as demandas sociais.

A responsável gestão das contas públicas, de acordo com Cruz e Afonso (2018), está relacionada a um processo de planejamento, controle, transparência e responsabilidade. A responsabilidade fiscal, de acordo com Cruz (2015), corresponde à capacidade de limitar gastos e gerir a dívida pública a níveis razoáveis para a manutenção da gestão pública, sem comprometer suas finanças, moldando o comportamento fiscal de todo o sistema financeiro nacional, compreendendo para tanto as ações dos entes federados, não se restringindo apenas ao governo central.

Considera-se ainda que, se tratando de um regime democrático, bem como a utilização de recursos públicos, é imprescindível que a gestão pública preste contas dos recursos aplicados e das ações executadas à sociedade, bem como ocorra fiscalização sobre essas contas e ações (PEREIRA; CORDEIRO FILHO, 2012).

Esses mecanismos partem da abordagem da accountability, que é entendida como a prestação de contas das ações realizadas pelo governo e pela administração pública, não somente por sua obrigação imposta por instrumentos legais, mas pelo interesse em ser transparente, além de englobar também a responsabilização dos atores envolvidos nas ações públicas.

De forma a garantir a melhor execução da gestão fiscal, foi estipulado pelo governo brasileiro em 2000, a Lei complementar 101, conhecida como Lei da Responsabilidade Fiscal (LRF), que estabeleceu "orientações normativas para que o aprimoramento da gestão fiscal dos recursos públicos fosse executada." (CAMARGO; SEHNEM, 2010, p. 252).

As instruções normativas estipuladas pela LRF dizem respeito à limitação de gastos com pessoal; estabelecendo limites percentuais de gastos, em especial relacionados à saúde e à educação; maior rigidez com o endividamento público, estabelecendo punições e definição de metas fiscais anuais (LOUREIRO; ABRUCIO, 2004), além da atenção da composição de instrumentos legais de planejamento da atividade fiscal, sendo eles a Lei de Diretrizes Orçamentárias (LDO), Lei Orçamentária Anual (LOA) e Plano Plurianual (PPA) (ARAÚJO; SANTOS FILHO; GOMES, 2015).

Apesar disso, diversos estados brasileiros relataram crises financeiras ao longo da segunda metade da década de 2010, com destaque para Minas Gerais, Rio de Janeiro e Rio Grande do Sul. O estado de Minas Gerais, em específico, iniciou em 2015 uma sequência de registros de déficit orçamentário, dificultando o repasse dos recursos para os municípios e comprometendo as finanças públicas municipais (MINAS GERAIS, 2018).

Diversos estudos buscaram identificar os efeitos da LRF sobre as contas públicas municipais e identificaram que, após a implantação da lei, houve melhoras na saúde fiscal dos municípios brasileiros e/ou no cumprimento das exigências fiscais junto a mecanismos de controle, tais como tribunais de contas (LEITE FILHO et al., 2015; CAMARGO; SEHNEM, 2010; SÖTHE; SÖTHE; GUBIANI, 2012).

A LRF estabeleceu ainda diretrizes aos entes federados (União, Estados e Municípios) abrangendo suas ações aos três poderes (executivo, legislativo e judiciário), bem como designou aos tribunais de contas o papel de fiscalizar o cumprimento dos normativos a respeito das contas públicas (ARAÚJO; SANTOS FILHO; GOMES, 2015).

Os Tribunais de Contas (TCs) foram criados no Brasil a partir da proclamação da república, quando Rui Barbosa, então ministro da fazenda do governo provisório, elaborou a norma de criação mediante o Decreto 966-A, de 7 de novembro de 1890, cujas atribuições consistiam em verificar a legalidade das receitas e despesas antes da prestação de contas junto ao congresso (MARANHÃO, 1992).

Embora tenha surgido nesse período, apenas com a Constituição de 1988 e, posteriormente, com a LRF, os TCs receberam maior atribuição, sendo incumbidos pela fiscalização das contas públicas (ROCHA; ZUCCOLOTTO, 2017).

Diversos estudos verificaram a relação dos TCs, considerando a accountability (ROCHA, 2013), o auxílio de tecnologias da informação para as prestações de contas (REIS; DACORSO; TENÓRIO, 2015), a avaliação das contas públicas junto com elementos ambientais (KRONBAUER et al., 2011) e divergências entre pareceres dos auditores técnicos e dos conselheiros dos TCs (LAUREANO et al., 2017). Tais estudos, de forma geral, buscaram elementos que visem a melhoria da gestão fiscal e da prestação de contas, bem como a compreensão dos motivos ambientais e, como no caso de Laureano et al. (2017), os motivos que influenciavam as decisões dos pareceres, no processo de avaliação das contas públicas. 
Apesar dos avanços que a Lei de Responsabilidade Fiscal apresentou para a melhoria da gestão fiscal (LEITE FILHO et al., 2015; CAMARGO; SEHNEM, 2010; SÖTHE; SÖTHE; GUBIANI, 2012) e da busca por mecanismos que viabilizem a prestação de contas junto aos TCs, ainda há descumprimentos e falhas por parte dos entes federados (União, Estados e Municípios), referentes às normas estabelecidas para a boa gestão fiscal.

Nesse sentido, o presente estudo tem por objetivo verificar os julgamentos das contas de governo dos municípios de Minas Gerais. De forma específica pretende: (1) verificar os municípios que obtiveram contas reprovadas; (2) verificar os municípios que obtiveram revisão das análises das contas públicas; (3) analisar as divergências nas análises do órgão técnico, do Ministério Público de Contas Estaduais e dos conselheiros do Tribunal de Contas do Estado de Minas Gerais. Além de considerar a crise financeira relatada (MINAS GERAIS, 2018), a escolha do estado de Minas Gerais como objeto de estudo também se baseia no fato de o estado apresentar o maior número de municípios, se comparado aos demais,, com a segunda maior população, contemplando o sexto maior e o menor município do país, em população (IBGE, n.d.). Ademais, Minas Gerais possui tanto municípios com elevado desenvolvimento socioeconômico quanto outros que se encontram estagnados economicamente ou com baixa estruturação econômica.

O presente estudo se difere dos demais (ROCHA, 2013; LAUREANO et al., 2017), ao tentar elencar elementos que levaram à rejeição das contas públicas no instante de sua prestação de contas. Desse modo, os resultados apresentados podem auxiliar a gestão pública a estabelecer estratégias para redução das falhas cometidas, bem como apresentar à teoria evidências empíricas de elementos que afetam a boa gestão fiscal.

\section{Referencial Teórico}

\subsection{Influências das funções fiscais na disposição do orçamento público}

O orçamento público parte da necessidade de previsão da aplicação de recursos, verificando sua disponibilidade e estabelecendo áreas em que serão aplicados. Trata-se da previsão de receitas e despesas, visando conciliar as duas forças divergentes, de forma a atender as demandas sociais sem desequilibrar a saúde fiscal do ente público (COSTA; GARTNER, 2017).

Trata-se de um instrumento formal, onde estão delineadas as receitas e as despesas públicas. Foi criado formalmente na Inglaterra no século XIX, embora já fosse previsto em sua carta Magna de 1207 que os gastos deveriam corresponder às receitas, sendo aplicado como um mecanismo de prestação de contas (GIACOMONI, 2010).

De acordo com Alesina e Perotti (1999), há dois argumentos teóricos que explicam que o equilíbrio orçamentário não deveria ser ótimo. O primeiro consiste na teoria anticíclica de Keynes, que indica serem intercalados períodos de crescimento de receitas e outros com crescimento de despesas. A segunda teoria, por sua vez, aponta que os gastos orçamentários e as reservas devem ser utilizados para suavizar momentos atípicos na economia, por meio de decisões tais como autorização do aumento dos gastos em períodos de guerras, catástrofes, ou da redução, quando as receitas forem temporariamente reduzidas.

Assim, Musgrave (1959) estabeleceu três funções da gestão fiscal: função estabilizadora, alocativa e distributiva. A função estabilizadora diz respeito à necessidade de manutenção fiscal e econômica, exercendo influências na inflação e estímulo ao crescimento econômico, e à dinâmica fiscal/econômica como um todo, a fim de minimizar variações que possam ser prejudiciais à economia e à sociedade (MUSGRAVE, 1959).

A alocação dos recursos corresponde à forma como o gestor pretende utilizar os bens públicos para atender um determinado problema público. Visa a oferta de bens e serviços que atendam toda a população, relacionados à saúde e à educação, a fim de corrigir falhas do mercado, que limitam o acesso do indivíduo que não possui recursos próprios para investir nesses benefícios (MUSGRAVE, 1959).

Além disso, ao considerar as diferenças entre as regiões de uma determinada localidade, as limitações dos indivíduos podem ser agravadas, haja vista a falta de recursos de regiões mais pobres, o que dificulta o investimento em políticas públicas e acesso a serviços básicos, diferentemente de regiões mais desenvolvidas, que possuem maior capacidade de investimento e promoção de políticas públicas que visem a melhoria das condições sociais.

Nesse contexto, a distribuição igualitária de recursos em ambientes desiguais pode agravar a desigualdade entre as regiões, favorecendo o desenvolvimento de regiões mais ricas e as tornando mais atrativas, como expressa Myrdal (1963). Assim, torna-se importante reconhecer as diferenças e promover a alocação de recursos de forma a beneficiar todas as regiões de forma semelhante.

Nesse sentido, surge o papel da função distributiva, que consiste no balanceamento da alocação dos recursos públicos arrecadados de todos os indivíduos. Por meio dela, as áreas de maior necessidade social e econômica têm prioridade, visto que o esforço local não seria capaz de atender as demandas sem auxílio dos recursos provenientes dessa distribuição (MUSGRAVE, 1959). Assim, para que se exerça a função distributiva, são consideradas a capacidade fiscal e a necessidade fiscal das regiões, estados e municípios. A capacidade fiscal corresponde ao quanto a localidade consegue arrecadar, considerando seu esforço e o desempenho da economia, enquanto a necessidade fiscal corresponde à oferta de serviços públicos, à demografia, ao desenvolvimento e à região (BAIÃO; CUNHA; SOUZA, 2017). Desse modo, o orçamento 
público deve atender certos princípios para se tornar de fato um elemento de planejamento e gestão das finanças públicas.

\subsection{Accountability e o mecanismo de apreciação das contas públicas}

A administração pública, seja na esfera federal, estadual ou municipal, tem como função precípua a promoção do bem-estar populacional. Por meio da prestação de serviços públicos, os gestores buscam compreender os problemas e demandas da sociedade (GERIGK; CLEMENTE; TAFFAREL, 2011). Contudo, é correto afirmar que a prestação de serviços à população não exime o administrador público de arcar com seus expressivos custos, trazendo sobre si uma demanda crescente de planejamento e controle financeiro para lidar com os recursos públicos.

Sem a presença de mecanismos de gerenciamento de gastos e mensuração de receitas ou até mesmo com a utilização de tais mecanismos de forma ineficiente, são inevitáveis a má utilização de recursos e o descontrole orçamentário, dado que o Estado tem suas despesas e receitas divididas entre os diversos entes subnacionais, muitos deles sem o aparato necessário para a manutenção de sua própria performance fiscal (MACEDO; CORBARI, 2009).

Além das diversas dificuldades de gerenciamento, há ainda a questão de desvios de conduta e da corrupção que, mesmo não fazendo parte de um plano ideal, mostram-se como percalços ao correto gerenciamento de recursos públicos. Sendo assim, além de ferramentas que possibilitem ao gestor uma administração eficaz, faz-se também necessária a presença de mecanismos de accountability que busquem trazer transparência e honestidade na apuração de custos no setor público (MACEDO; CORBARI, 2009).

Por vezes, a accountability é retratada como um simples processo de prestação de contas. O termo, contudo, ainda sofre com a falta de tradução e de consenso na literatura sobre seu real conceito, sendo por vezes retratada como uma forma de controle do agente público (GRANT; KEOHANE, 2005), ou se traduzindo na responsabilização do poder público perante a sociedade (ABRUCIO; LOUREIRO, 2004; ROCHA, 2013), ou ainda como o próprio conceito de prestação de contas e transparência (SCHEDLER, 1999). Este estudo considerará a conceituação adotada por O'Donnell (1994), em que classificou a accountability em duas abordagens: a Vertical e a Horizontal.

A accountability Vertical revela-se como as ações dos eleitores sobre os agentes públicos, sendo exercida em especial no momento da eleição (MANIN; PRZEWORSKI; STOKES, 1999). Assim, a avaliação dos agentes públicos, realizada com base nessa abordagem, deve-se refletir nos resultados das eleições.

A accountability Horizontal, por sua vez, acontece quando instituições de mesmo nível realizam avaliação e controle das demais entidades públicas, tendo como característica o uso de agências estatais para averiguar a utilização dos recursos públicos e as ações executadas por esses órgãos (O'DONNELL, 1994; O'DONNELL, 2003; VIEIRA, 2005). Nessa abordagem se encontram os Tribunais de Contas, que exercem atividades de controle, fiscalização e punição de entidades estatais, tais como municípios, estados e União, além das autarquias por elas coordenadas.

Dessa forma, a avaliação das contas públicas parte de um processo de accountability, no qual há a responsabilização da gestão pública em prestar contas e a necessidade de se controlar o órgão público, a fim de manter sua saúde financeira.

\subsection{A Lei de Responsabilidade Fiscal e o controle das contas públicas no Brasil}

Com o crescente endividamento público corrente no Brasil na década de 1990 e a ausência de leis rígidas de regulamentação de gastos dos entes federativos, houve a necessidade de criação de mecanismos mais severos para contenção das despesas e controle orçamentário, os quais pudessem assegurar mais rigidez à normatização e mais clareza ao processo de prestação de contas.

Nesse contexto, a demanda pela eficiência da administração pública e pela garantia do equilíbrio fiscal levou, posteriormente, à criação da Lei complementar n. 101, de 2000, nomeada Lei de Responsabilidade Fiscal ou simplesmente LRF. Essa lei tem como pilares o planejamento, o controle, a transparência e a responsabilidade e visa alcançar, dentre seus demais objetivos, o resultado fiscal positivo das camadas de governo, por meio do estabelecimento de diversas metas com a finalidade de obtenção de recursos para custeamento dos gastos públicos (ANDRADE; FORTES, 2005).

De acordo com Paiva et al. (2015, p. 177), a LRF é "um código de conduta administrativa que deve ser cumprido por todos os gestores públicos do país", cujo cuidado com a gestão fiscal é capaz de prevenir riscos e desvios que impactam a saúde das contas públicas, considerando o planejamento das contas, receitas e despesas e metas a serem alcançadas (BRASIL, 2000).

A LRF, contudo, não criou um modelo novo de gestão, apenas seguiu o princípio constitucional para compor a responsabilidade fiscal, interligando a Lei de Diretrizes Orçamentárias (LDO), a Lei Orçamentária Anual (LOA) e o Plano Plurianual (PPA). Foram limitadas as receitas públicas quanto às renúncias, arrecadações e previsões, além da orientação da responsabilidade com a gestão fiscal, prevendo penalidades para os entes que não cumprirem a norma, incluindo, nessas penalidades, o impedimento de receber transferências voluntárias de outros entes (ARAÚJO; SANTOS FILHO; GOMES, 2015). 
A Lei de Diretrizes Orçamentárias (LDO) é um conjunto de metas fiscais que dispõe sobre o equilíbrio entre receitas e despesas, critérios e formas de limitação de empenho, controle de custos e avaliação de resultados de programas financiados pelo orçamento, de forma a guiar e estruturar os demais mecanismos de controle e gestão (BRASIL, 2000).

De forma compatível, a Lei Orçamentária Anual (LOA) dispõe também sobre o que versa a Lei das Diretrizes Orçamentárias, de forma mais detalhada, especificando as metas do exercício seguinte e contemplando, dentre outros pontos, todas as despesas relativas à dívida pública, mobiliária ou contratual, e todas as receitas que as atenderão (BRASIL, 2000). A LOA busca ser harmônica ao conteúdo da LDO e alinhada com o Plano Plurianual, um orçamento desenvolvido para o período de quatro anos.

Sobre a forma desses instrumentos legais de gestão, a LRF impôs competências aos três entes federados (União, Estados e Municípios), estendidas aos três poderes (executivo, legislativo e judiciário), bem como aos Tribunais de Contas (ARAÚJO; SANTOS FILHO; GOMES, 2015). Ao poder executivo, ficou o papel de criar formas de gestão dos recursos. Ao poder legislativo, entre outros atributos, o papel de fiscalização orçamentária. O poder judiciário e o Ministério Público ficaram responsáveis por garantir a sobrevivência da democracia. Os Tribunais de Contas, por sua vez, ficaram incumbidos de fiscalizar a aplicação dos recursos públicos e as ações públicas, apontando caminhos para cumprimento da lei e punindo agentes quando há mal uso dos recursos (ARANTES et al., 2010).

Os Tribunais de Contas (TCs) exercem um importante e necessário papel de controle externo das ações do governo, de forma a identificar falhas e usos inadequados dos recursos públicos, com o objetivo de melhorar a gestão fiscal dos municípios (KRONBAUER, et al., 2011). Os TCs surgiram no Brasil em 1890, no intuito de examinar as receitas e despesas públicas, tomando status constitucional a partir de 1891 (LAUREANO et al., 2017). Esses tribunais, embora existentes desde a independência do Brasil, receberam maior autonomia a partir da Constituição Federal de 1988 e somente com a LRF obtiveram maior atribuição (LOUREIRO; ABRUCIO, 2004).

Essa autonomia dada aos TCs, não subordinada a nenhum órgão, além das funções técnicas e jurisdicional que eles possuem, aproximam esses órgãos da essência da accountability, ao ponto que possibilitam sua atuação como instrumentos de controle social, o que destaca a importância de suas análises serem realizadas de forma ampla e completa (ROCHA, 2013). Por esse motivo, Arantes et al. (2010) apontam que os TCs são os órgãos mais eficientes e completos no aparato institucional brasileiro de accountability, ainda que sua atuação precise de avanços e melhorias..

Em Minas Gerais, a avaliação das contas municipais, ocorre por meio da análise do cumprimento dos limites de gastos com Saúde, Educação, Pessoal, Repasse para o legislativo e Abertura de créditos (MINAS GERAIS, 2015), contudo outros pontos não previstos são observados pelo tribunal, em busca de falhas que possam comprometer a saúde fiscal dos municípios, indicando elementos que possam ser redirecionados e caminhos, corrigidos.

Essas atribuições e o aumento da autonomia são essenciais para um órgão que visa o controle da gestão pública, uma vez que a análise das contas públicas, com destaque para as contas dos poderes executivo e legislativo, exige aparato legal e jurídico e distanciamento dos interesses políticos/partidários. Apenas desse modo se torna possível a execução efetiva das ações de controle realizadas pelos tribunais.

\section{Procedimentos Metodológicos}

A fim de atender o objetivo proposto, será realizada uma análise documental, que consiste em um procedimento qualitativo, cujo objetivo é verificar um determinado fenômeno, por meio da análise de documentos, anulando a possibilidade de reação do sujeito frente ao registro (CELLARD, 2008). A partir das análises, foram ainda quantificados elementos para observar características de comportamento documental.

No ambiente eletrônico do Tribunal de Contas do Estado de Minas Gerais (TCEMG), foram considerados os relatórios de avaliação das contas anuais de governos, que avaliam a prestação de contas anuais de cada prefeitura do estado de Minas Gerais, emitidos para os municípios sorteados para análises para cada ano de estudo. Foram pesquisados, no sítio eletrônico TCJuris, que corresponde ao banco de dados de relatórios do TCEMG, os relatórios de contas de governo referentes ao ano de 2015 . O ano de 2015 foi selecionado por ser o ano mais recente com mais de $50 \%$ dos municípios mineiros com contas avaliadas.

Foi selecionado como termo de pesquisa a expressão "Exercício: 2015", pesquisado em "inteiro teor", que corresponde à busca da expressão pesquisada no relatório completo, não somente em sua ementa e/ou indexações, que correspondem, nos relatórios, ao resumo e palavras-chaves respectivamente. Na natureza dos relatórios, foi selecionado "PCTAS EXECUTIVO MUNICIPAL", que corresponde aos relatórios de prestação de contas de governo do poder executivo municipal. Em decisão, foram selecionados os campos "colegiada" e "monocrática", de forma a encontrar todos os relatórios já emitidos para os municípios no ano pesquisado. A pesquisa foi realizada entre os dias 18 de julho de 2018 e 4 de setembro de 2018, sendo encontrados 684 municípios com relatórios emitidos pelo TCEMG.

Tais documentos são considerados como documentos públicos, cujo acesso é garantido pela Lei $\mathrm{n}^{0}$ 12.527, de 25 de novembro de 2011, que limita o sigilo dos documentos e, consequentemente, amplia o acesso à informação (BRASIL, 2011). 
Coletados os documentos, parte-se para o processo de análise, que tem por finalidade a identificação das informações oferecidas pelos documentos, considerados como objetos sem qualquer tipo de análise realizada anteriormente por outro investigador ou em outra investigação (LÜDKE; ANDRÉ, 1986). As análises dos documentos iniciarão a partir do que indica Cellard (2008). No primeiro momento será realizada uma análise prévia dos documentos, considerando contexto, natureza, órgão emissor e assunto chave.

Assim, os documentos selecionados serão separados em cinco grandes grupos iniciais: Contas aprovadas em primeira análise pelo TCEMG; Contas rejeitadas em primeira análise pelo TCEMG; Contas aprovadas em segunda análise pelos Técnicos, MP de contas e conselheiros; Contas rejeitadas em segunda análise; Contas com divergências em decisões dos técnicos, MP de contas e conselheiros.

Após a classificação por grupos resultante da análise prévia, Cellard (2008) recomenda que se inicie o processo de investigação desses documentos. A interpretação deve ocorrer de forma sistemática, condizente com o aparato teórico e confrontada com outras fontes, a fim de obter robustez e validade dos resultados encontrados.

As análises desses documentos, considerando uma investigação sistemática, possibilitarão verificar alguns pontos semelhantes e divergentes nos municípios mineiros, a fim de identificar quais motivos levaram às tais divergências. Nesse caso, foram consideradas as categorias de análises prévias dos documentos descritas no Quadro 1.

Quadro 1: Descrição das categorias de análises

\begin{tabular}{|c|c|c|}
\hline Categoria & Descrição & Argumentação teórica/legal \\
\hline $\begin{array}{l}\text { Resultado do } \\
\text { parecer }\end{array}$ & $\begin{array}{l}\text { Emissão de cada análise, considerando as análises } \\
\text { do órgão técnico (corresponde aos servidores } \\
\text { técnicos do TCEMG que verificam as contas } \\
\text { públicas dos municípios com base na legislação } \\
\text { presente), do Ministério Público Estadual de Contas } \\
\text { (após análise do órgão técnico, realiza uma nova } \\
\text { verificação das contas públicas e emite suas } \\
\text { considerações, tendo como base o relatório } \\
\text { técnico) e o parecer final (emitido pelo conselheiro } \\
\text { relator, após as análises do órgão técnico e do MP } \\
\text { de contas, em que passa por um colegiado de } \\
\text { conselheiros que votam a aprovação ou não das } \\
\text { contas). }\end{array}$ & $\begin{array}{l}\text { Tem como base a Lei Complementar do estado de } \\
\text { Minas Gerais de número 102, de } 17 \text { de janeiro de } \\
2008 \text { (LC 102/2008), que dispõe sobre a } \\
\text { organização do Tribunal de Contas do Estado. Na } \\
\text { presente Lei, há o artigo } 45 \text { que aponta } 3 \text { possíveis } \\
\text { deliberações para os pareceres, sendo elas: } \\
\text { Aprovação, quando fica evidente o cumprimento } \\
\text { das normas fiscais e da boa gestão; Aprovação } \\
\text { com ressalvas, quando há falhas no processo das } \\
\text { contas públicas, mas sem prejuízo ao erário, e; } \\
\text { Rejeição, quando ficam evidentes atos de gestão } \\
\text { que descumprem normas legais e constitucionais } \\
\text { (MINAS GERAIS, 2008). }\end{array}$ \\
\hline $\begin{array}{l}\text { Relator do } \\
\text { documento }\end{array}$ & $\begin{array}{l}\text { O relator do documento corresponde ao nome do } \\
\text { conselheiro do TCEMG responsável pela emissão } \\
\text { do relatório, tomando como base os pareceres } \\
\text { emitidos pelo órgão técnico e pelo MP de contas. O } \\
\text { nome foi substituído por códigos para não } \\
\text { identificação do relator. }\end{array}$ & $\begin{array}{l}\text { Os conselheiros são escolhidos e nomeados pelo } \\
\text { chefe do poder executivo, considerando as } \\
\text { prerrogativas estabelecidas pelos artigos } 7^{\circ} \text { e } 8^{\circ} \text { da } \\
\text { LC } 102 / 2008 \text { (MINAS GERAIS, 2008). }\end{array}$ \\
\hline $\begin{array}{l}\text { Divergências } \\
\text { entre os órgãos } \\
\text { técnicos, MP de } \\
\text { contas e } \\
\text { conselheiros }\end{array}$ & $\begin{array}{l}\text { Considerando o conhecimento e análise de cada } \\
\text { órgão avaliativo, embora a decisão deliberativa seja } \\
\text { tomada pelo colegiado de conselheiros, o } \\
\text { entendimento de cada ator quanto ao cumprimento } \\
\text { das normas pode variar. }\end{array}$ & $\begin{array}{l}\text { Nesse sentido, optou-se por compreender como } \\
\text { cada órgão de avaliação aplicou critérios para } \\
\text { analisar as contas públicas, podendo tomar } \\
\text { decisões contrárias quanto ao parecer, } \\
\text { considerando as três possíveis decisões do Artigo } \\
45 \text { da LC 102/2008, quais sejam aprovação, } \\
\text { aprovação com ressalvas e rejeição (MINAS } \\
\text { GERAIS, 2008). }\end{array}$ \\
\hline $\begin{array}{l}\text { Áreas de } \\
\text { análise (Saúde, } \\
\text { Educação, } \\
\text { Gastos com } \\
\text { pessoal, } \\
\text { Repasse para o } \\
\text { legislativo e } \\
\text { Abertura de } \\
\text { créditos) }\end{array}$ & $\begin{array}{l}\text { Consistem nas áreas principais de análise da } \\
\text { prestação de contas dos municípios, destacadas } \\
\text { pela Constituição Federal, que estabelece limites } \\
\text { mínimos de gastos com serviços de Saúde e } \\
\text { Educação, além do limite máximo de repasses para } \\
\text { o poder legislativo e de abertura de créditos } \\
\text { (BRASIL, 1988). Além da Constituição Federal de } \\
\text { 1988, a LRF estabeleceu o máximo de gastos } \\
\text { estipulados para folhas de pagamento (BRASIL, } \\
\text { 2000). }\end{array}$ & $\begin{array}{l}\text { Esses limites foram ainda apontados pela Instrução } \\
\text { Normativa número 02/2015, do TCEMG, em seu } \\
\text { anexo I, como elementos para prestação de contas } \\
\text { e verificação (MINAS GERAIS, 2015). }\end{array}$ \\
\hline $\begin{array}{l}\text { Os tipos de } \\
\text { falhas }\end{array}$ & \multicolumn{2}{|c|}{$\begin{array}{l}\text { Consistem nas falhas operacionais indicadas pelo relatório, cometidas pelo poder executivo municipal, } \\
\text { que não foram consideradas falhas por má fé, mas que comprometem o bom ajustamento das contas } \\
\text { públicas, em especial em seu julgamento. Nesse caso, não foram contabilizadas a quantidade de falhas, } \\
\text { uma vez que os relatórios apontam apenas a existência ou não das falhas, sem as quantificar. Assim, } \\
\text { foram consideradas a quantidade de tipos de falhas, tendo em vista que para cada tipo de falha há } \\
\text { registros nos relatórios. Os tipos de falhas, neste caso, são considerados formas diferentes de ocorrência } \\
\text { de falhas. }\end{array}$} \\
\hline $\begin{array}{l}\text { Análises } \\
\text { diversas, não } \\
\text { previstas pela } \\
\text { legislação }\end{array}$ & \multicolumn{2}{|c|}{$\begin{array}{l}\text { Esta categoria consiste na identificação de outros elementos verificados pelo TCEMG que não são } \\
\text { previstos pela Instrução Normativa } 02 / 2015 \text {, mas que servem de alerta ao gestor público para a boa } \\
\text { gestão. }\end{array}$} \\
\hline
\end{tabular}

Fonte: Elaborado pelos autores 


\section{Resultados e Discussões}

Dos 684 relatórios avaliados, 629 obtiveram pareceres finais aprovando as contas, quatro foram aprovados com ressalvas e 51 tiveram rejeições de contas (ver Figura 1). Desse total, 329 relatórios passaram por mais de uma análise, visto que foram encontradas irregularidades em suas contas, fazendo-se necessário que o gestor público prestasse esclarecimentos; 37 municípios não conseguiram justificar ou as justificativas não foram consideradas suficientes pelo TCEMG para aprovação das contas (ver Tabela 1).

Figura 1: Decisões do Plenário do TCE-MG para as Contas de Governo Municipal.

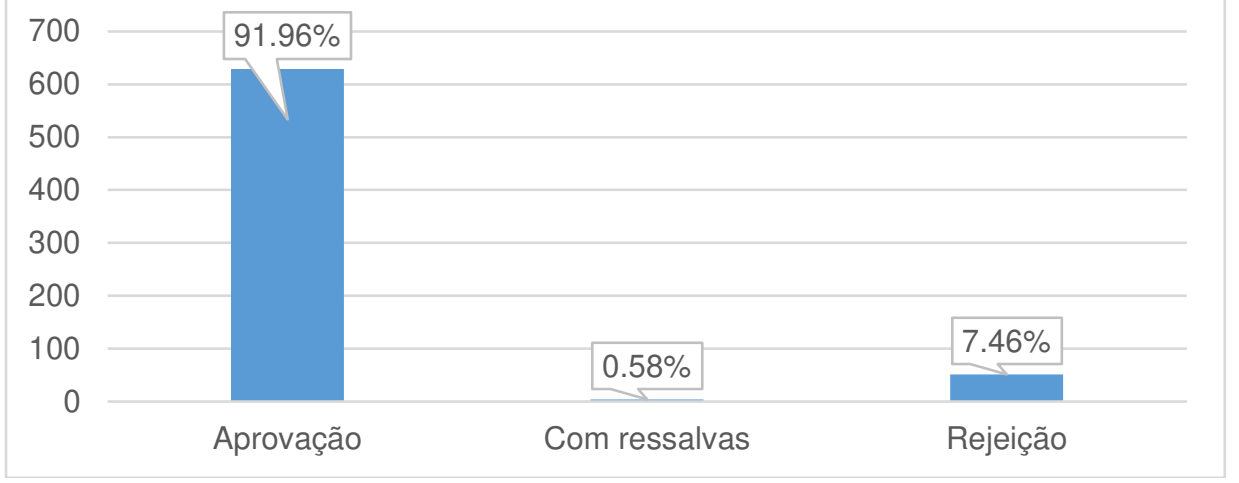

Fonte: dados da pesquisa

Apesar de ainda ocorrerem rejeições, Camargo e Sehnem (2010) relatam que a LRF auxiliou na redução das reprovações das contas públicas, uma vez que apresentou os pontos que precisam de mais atenção por parte dos gestores públicos e as metas a serem cumpridas, além de estabelecer punição ao agente público que não cumprir as normas elencadas.

Tabela 1: Distribuição de relatórios por conselheiro

\begin{tabular}{|c|c|c|c|c|c|c|c|}
\hline \multirow{2}{*}{ Conselheiro* } & \multirow{2}{*}{ Total } & \multicolumn{3}{|c|}{ Resultado do Parecer } & \multicolumn{2}{|c|}{ Divergência com } & \multirow{2}{*}{$\begin{array}{c}\text { Segunda } \\
\text { análise }\end{array}$} \\
\hline & & Aprovação & Com ressalvas & Rejeição & MP de contas & Técnico & \\
\hline Cons. 1 & 72 & 68 & 0 & 4 & 21 & 9 & 23 \\
\hline Cons. 2 & 9 & 9 & 0 & 0 & 2 & 0 & 0 \\
\hline Cons. 3 & 86 & 77 & 0 & 9 & 27 & 8 & 41 \\
\hline Cons. 4 & 107 & 97 & 0 & 10 & 28 & 14 & 55 \\
\hline Cons. 5 & 95 & 81 & 0 & 14 & 14 & 18 & 54 \\
\hline Cons. 6 & 53 & 48 & 1 & 4 & 2 & 2 & 22 \\
\hline Cons. 7 & 86 & 83 & 0 & 3 & 24 & 14 & 40 \\
\hline Cons. 8 & 84 & 81 & 3 & 0 & 18 & 20 & 49 \\
\hline Cons. 9 & 92 & 85 & 0 & 7 & 24 & 13 & 45 \\
\hline Total & 684 & 629 & 4 & 51 & 160 & 98 & 329 \\
\hline
\end{tabular}

Fonte: Dados da pesquisa.

Notas: *Apesar de serem informações públicas, os autores optaram por preservar o nome dos servidores, representantes ou autoridades.

Quando membros do órgão técnico ou do MP de contas detectam irregularidades nas prestações de contas, as devidas justificativas são solicitadas ao prefeito da época. Ao todo, 23 prefeitos do ano de 2015 que foram citados para apresentar justificativas quanto a irregularidades encontradas não se manifestaram. Esse fato contraria o pressuposto da accountability, seja ela considerada como forma de controlar (GRANT; KEOHANE, 2005), responsabilizar (ABRUCIO; LOUREIRO, 2004; ROCHA, 2013) ou prestar contas à sociedade (SCHEDLER, 1999).

Das 51 prestações de contas rejeitadas, catorze prefeitos em exercício à época não se manifestaram quanto à revisão e não apresentaram justificativas, o que levou os conselheiros do TCEMG a acatarem o parecer de rejeição. Cabe ressaltar que o município de Morro do Pilar solicitou dilação do prazo de defesa, o que não foi acatado pelo TCEMG por não se apresentar excepcionalidade no caso que justificasse o aumento do prazo.

Além disso, oito municípios, sendo eles Coronel Murta, Poté, Sobrália, Itambacuri, Araponga, Paineiras, Patrocínio do Muriaé e Santana do Jacaré, mesmo sem justificativa apresentada pelo prefeito ou por algum responsável, obtiveram contas aprovadas pelos conselheiros do TCEMG, contrariando o recomendado pelo órgão técnico.

Em Coronel Murta, Poté e Sobrália, apesar de constatado o descumprimento com gastos com pessoal, observou-se que os valores excedentes conseguiram ser reconduzidos para o teto dos gastos no período de dois quadrimestres, conforme estipulado pela LRF (BRASIL, 2000). Em Itambacuri, o valor excedente correspondia a gastos realizados pelo Serviço Autônomo de Água e Esgoto (SAAE), serviço 
autônomo com orçamento próprio, do que se compreendeu que a irregularidade deveria ser imputada ao responsável pelo órgão. Em Araponga e Paineiras, por sua vez, houve despesas excedentes aos créditos concedidos, o que configurou descumprimento do artigo 59 da Lei 4.320 de 1964 (BRASIL, 1964) No entanto, a aprovação das contas ocorreu com base na aplicação do princípio da razoabilidade, visto que o valor excedente foi menor que $1 \%$ do orçamento aprovado.

Já a prestação de contas de Patrocínio do Muriaé foi reprovada pelo órgão técnico, em razão de abertura de crédito sem receita. Apesar da ausência de manifestação do prefeito, o relator do TCEMG verificou que não houve empenho de despesas relacionadas à abertura, do que depreendeu, conforme exposto no relatório, que não houve interesse do gestor em burlar a lei. O órgão técnico ainda constatou abertura de crédito sem aprovação legal, mas foi verificado pelo relator a ocorrência de falha na citação do instrumento legal que autoriza a abertura de crédito dentro do SICOM.

Em Santana do Jacaré, o órgão técnico constatou abertura de créditos sem recursos em fonte. Contudo, o relator do caso verificou que o município utilizou recursos de uma fonte originária, o que é permitido. A prestação de contas realizada pelo município de Paulistas, embora aprovada pelo órgão técnico, levou o MP de contas a solicitar vistas ao prefeito, devido à execução de despesas além dos créditos concedidos. Ainda que o prefeito não tenha se manifestado, o relator do processo aprovou a prestação de contas ao aplicar o princípio da razoabilidade, haja vista a baixa expressividade do valor excedido.

Apenas o município de Congonhas do Norte obteve alteração da decisão. Após aprovação inicial, o órgão técnico realizou revisão de seu parecer, a pedido do MP de contas, alterando-o para rejeição das contas, visto que constava da prestação despesa excedente ao crédito autorizado. Este novo entendimento foi adotado pelo MP e pelos conselheiros do TCEMG em julgamento.

Ao todo, 333 municípios (48,62\% do total) não obtiveram problemas em suas contas que necessitassem de citação do prefeito para esclarecimentos, sendo apenas apontadas algumas recomendações à gestão pública quanto ao cumprimento de normas para o bom desempenho da gestão. Os relatórios foram emitidos por nove conselheiros diferentes, conforme pode ser observado na Tabela 1. Notase um grande volume de divergências de entendimentos entre os pareceres do órgão técnico, que rejeitou 146 contas, do MP de contas, que rejeitou 136 contas, e dos conselheiros, que rejeitaram 51 . Resultados semelhantes foram encontrados por Laureano et al. (2017), que identificaram uma divergência de 59,55\% dos casos auditados no Rio Grande do Sul.

O MP de contas e o órgão técnico possuem análises mais objetivas para avaliação das contas. Seus argumentos partem puramente do cumprimento ou não dos limites constitucionais. A adoção de medidas rígidas, por sua vez, pode dificultar o município no recebimento de transferências, reduzindo sua capacidade financeira e impactando no orçamento municipal. Dessa forma, os conselheiros do TCEMG adotam medidas parcimoniosas, invocando princípios de insignificância e proporcionalidade para minimizar os efeitos de reprovação de contas, solicitando melhorias para exercícios futuros.

Ao passo que buscam facilitar o caminho para a gestão pública municipal, medidas flexíveis podem propiciar um ambiente de impunidade ao gestor público que não cumpre a legislação. Ainda, relativiza as atividades realizadas pelo órgão técnico e MP de contas a apenas consultivas, considerando a divergência em $14,33 \%$ para o órgão técnico e $23,39 \%$ para o MP de contas.

As prestações de contas cujos pareceres foram relatados pelo Cons. 6 foram as que obtiveram menor diferença de interpretação com o MP de contas e com o órgão técnico, em proporção com o total examinado pelo relator (3,7\% de divergência de parecer para o MP de contas e o órgão técnico). Cons. 7 e Cons. 8 foram os relatores que tiveram maior volume proporcional de aprovação das contas, com 96,51\% e 96,43\% respectivamente. Por outro lado, os processos de prestação cujo relator foi o Cons. 5 consistiram nos que obtiveram maior volume de rejeição, tanto proporcionalmente ao avaliado pelo relator (14,74\%) quanto em valores absolutos (14).

Apenas dois conselheiros trabalharam em pareceres que obtiveram aprovações com ressalvas nos relatórios finais: o Cons. 6 aprovou com ressalvas a prestação de contas de um município, e o Cons. 8, a de três. Cabe ressaltar ainda que Cons. 8 foi o único conselheiro cujo nenhum relatório obteve parecer para rejeição das contas.

Ao longo das análises dos relatórios, as falhas foram agrupadas em seis tipos, conforme as especificações dos relatores. As falhas foram divididas em Falha na elaboração da legislação, Falha na geração de arquivos no SICOM, Falha ao seguir normas e legislação, Falha na inserção de dados no SICOM, Falha na alocação de contas de despesas e Falha na citação de leis para créditos suplementares, conforme pode ser observado na Tabela 2.

Apesar das falhas constatadas, muitas outras foram passíveis de correção e de cruzamentos de dados com outros órgãos, a fim de melhorar o processo de controle e avaliação das contas públicas. É importante destacar ainda que, apesar das falhas, de acordo com Reis, Dacorso e Tenório (2015), os sistemas de Tecnologias da Informação e Comunicação auxiliaram tanto as prefeituras para a emissão das contas, quanto os Tribunais de Contas em seu processo de análise das contas públicas, facilitando para os TCs, na comparação com outros municípios, cruzar dados e melhorar suas atividades de controle das contas públicas, servindo de auxílio para as análises de auditorias in loco. 
Tabela 2: Tipos de falhas por frequência

\begin{tabular}{lll}
\hline Falha & Frequência & Percentual \\
\hline Inserção de dados no SICOM & 113 & $39,79 \%$ \\
\hline Alocação das contas de despesas & 110 & $38,73 \%$ \\
\hline Elaboração da legislação & 6 & $2,11 \%$ \\
\hline Geração de arquivos no SICOM & 16 & $5,63 \%$ \\
\hline Citação de leis para créditos suplementares & 21 & $7,39 \%$ \\
\hline Seguir normas e legislação & 18 & $6,37 \%$ \\
\hline Total de falhas & 284 & $100 \%$ \\
\hline Fonte: dados da pesquisa & &
\end{tabular}

As falhas encontradas, em diversas situações, como o caso de inserção de dados no SICOM e de Geração de arquivos no SICOM, nem sempre ocorrem por má fé do agente público, mas pela complexidade do texto legal, que por vezes causa confusão no entendimento, inclusive pelos próprios agentes fiscalizadores, visto as divergências para aplicação do punitivo legal, como descrito na Tabela 1.

Embora os municípios pudessem cometer várias falhas, foram computados apenas os tipos de falhas, uma vez que um erro cometido pudesse comprometer várias áreas, dificultando quantificar o total de falhas. Nesse sentido, ao adotar a análise por tipos de falhas, é possível identificar falhas de diferentes naturezas cometidas pelos municípios.

Assim, não foram identificadas falhas cometidas pelos agentes públicos na prestação de contas de 449 municípios. Cabe ressaltar que neste grupo estão municípios que obtiveram aprovações diretas, sem necessidades de esclarecimentos ao TCEMG quanto a divergências encontradas. Apenas dois municípios cometeram quatro tipos de falhas, e outros dois também cometeram três tipos de falhas.

Ao todo, 192 municípios cometeram apenas um tipo de falha na prestação de contas. Destacaramse, neste caso, as falhas de Inserção de dados no SICOM e de Alocação das contas de despesas, de modo que, neste grupo, 82 municípios cometeram cada tipo de falha. Ao verificar os municípios que cometeram duas falhas, foram encontrados 39 relatos, sendo que 19 cometeram, em conjunto, as falhas de Inserção de dados no SICOM e de Alocação das contas de despesas.

As falhas. quanto a alocação das contas de despesas, ocorreram devido à falta de observância do fundo em que se deveriam aplicar as despesas sendo, por vezes, aplicadas em contas equivocadas. Essa falha gerou solicitações de vistas ao prefeito, como ocorreu em Arinos, o que não interferiu na aprovação das contas, como descreve o relatório:

A unidade técnica procedeu à glosa de despesas incorretamente classificadas como alocadas na manutenção do ensino, sendo $R \$ 65.211,23$, relativos à alimentação escolar $(\mathrm{R} \$ 64.442,58)$ e a pagamento efetuado com recursos oriundos de conta diversa da decorrente de impostos e transferências $(R \$ 768,65)$. Ainda assim, a aplicação no ensino importou em $30,36 \%$ da respectiva base de cálculo, cumprindo-se a exigência constitucional (Relatório município de Arinos).

Em Passabém, por sua vez, foram aplicados recursos de royalties do petróleo para pagamento de despesas de Saúde e Educação, o que aconteceu para que o município pudesse cumprir com o mínimo de investimento nessas áreas, imposto constitucionalmente. Contudo, os recursos dos royalties do petróleo não entram no cálculo para cumprimento do mínimo constitucional. Mesmo com as devidas deduções, o município ainda cumpriu o investimento com a saúde e educação, conforme previsto pelo instrumento legal.

Em Ibiracatu, por exemplo, houve falha na inserção de dados no SICOM, o que levou o órgão técnico a identificar problemas em abertura de créditos sem cobertura legal e em abertura de créditos sem recursos disponíveis. Após reenvio dos dados ao sistema, os técnicos acataram as correções e aprovaram as contas do município.

As falhas de elaboração da legislação dizem respeito a problemas na formulação da legislação, em especial na abertura de créditos, como o ocorrido em Sapucaí-Mirim em que o relatório destaca:

Na defesa apresentada às fls. 33 a 35, o gestor argumentou que o Decreto № 1593, de 2015, anulou indevidamente a fonte de recurso 190, utilizada por meio do Decreto oㅜ 1551, de 2015, quando o correto seria manter o saldo a empenhar, tendo em vista que os recursos esperados não foram efetivamente arrecadados e a despesa não foi empenhada (Relatório município de Sapucaí-Mirim).

Após comprovação, o órgão técnico atestou a confiabilidade do argumento e considerou sanada esta irregularidade. Falhas na geração de arquivos no SICOM acontecem quando o sistema informatizado da prefeitura possui problemas de compatibilidade com o SICOM, ocasionando ausência de informações e/ou equívoco de transmissão de informações ao sistema, como aponta o relatório do município de Natércia:

Ressaltou que "A transferência foi feita utilizando a DR 154, porém, houve um erro na geração do arquivo AOC do Sicom Módulo Acompanhamento Mensal de fevereiro de 2015, no arquivo foi informada a DR 155 acarretando um saldo negativo de $\mathrm{R} \$ 4.919,21$." Por fim, informa que está procedendo o reenvio do Sicom para regularização do citado erro (Relatório município de Natércia). 
Assim como o município de Nacip Raydan:

Alegou, ainda, que a divergência pode ter ocorrido por falhas na geração dos arquivos de Acompanhamento Mensal e enviados por meio do SICOM das competências mensais do exercício em referência (Relatório município de Nacip Raydan).

Em ambas situações, tanto o órgão técnico quanto o relator do parecer consideraram sanadas as irregularidades encontradas. O tipo de falha ao seguir normas e legislação corresponde a um conjunto de falhas que atestam contra dispositivos legais, tais como os que apontam sobre a observância do princípio contábil da anualidade, ou quanto à falta de separações de contas, como ocorreu em Conceição do Mato Dentro, por exemplo.

Em Albertina, por outro lado, a fim de solucionar uma falha na abertura de créditos por um decreto, foi emitido um segundo decreto em 2016, o que não foi acatado pelo órgão técnico, nem pelos conselheiros do TCEMG, como aponta o relatório:

Inicialmente destaca-se que a modificação procedida pelo Decreto 930, de 22/11/2016, fls. 57 e 58, não pode ser acatada, tendo em vista ter sido realizada quase um ano após a conclusão da execução orçamentária do exercício de 2015, o que contraria o princípio contábil da anualidade (Relatório município de Albertina).

A última falha constatada diz respeito à citação da lei para créditos suplementares, tratando-se de ocorrências em que o município, no instante de inserir a abertura de crédito, cita erroneamente uma legislação específica enquanto deveria referenciar o instrumento legal que deu base para essa abertura de crédito, como pode ser visto no relatório de Pratápolis:

[...] foram informados como vinculados à Lei Municipal ํo 1.808, de 12/12/2014 (LOA), quando, na verdade, deveriam estar vinculados à Lei Municipal oㅜ 1.797, de 18/06/2014 (LDO). Houve a regularização do arquivo AOC do SICOM, sanando a irregularidade (Relatório município de Pratápolis).

De acordo com Kronbauer et al. (2011), a redução das irregularidades se dá a partir de um controle interno mais ativo. Apesar da recomendação da maior atividade do controle interno, há ainda municípios cuja ação ocorre de forma de difícil execução, como em Frei Lagonegro, em que os técnicos identificaram que o controle interno do município era executado pelo próprio contador, responsável pela emissão das contas no sistema. Embora não haja um impedimento legal, os técnicos argumentaram que tal controle pode não ocorrer de forma efetiva e possibilitar o erro na gestão fiscal.

Quanto ao cumprimento com os limites legais e constitucionais, destaca-se que o não cumprimento dos gastos com Saúde (15\%) e com a Educação (25\%) resultavam em rejeição direta das contas, sendo os únicos motivos que levaram isoladamente a essa decisão, como pode ser observado pela Figura 2. Dos oito que não cumpriram o mínimo constitucional com saúde, três também não atenderam o mínimo com a educação.

Figura 2: Distribuição da classificação das contas por área de investigação conforme legislação

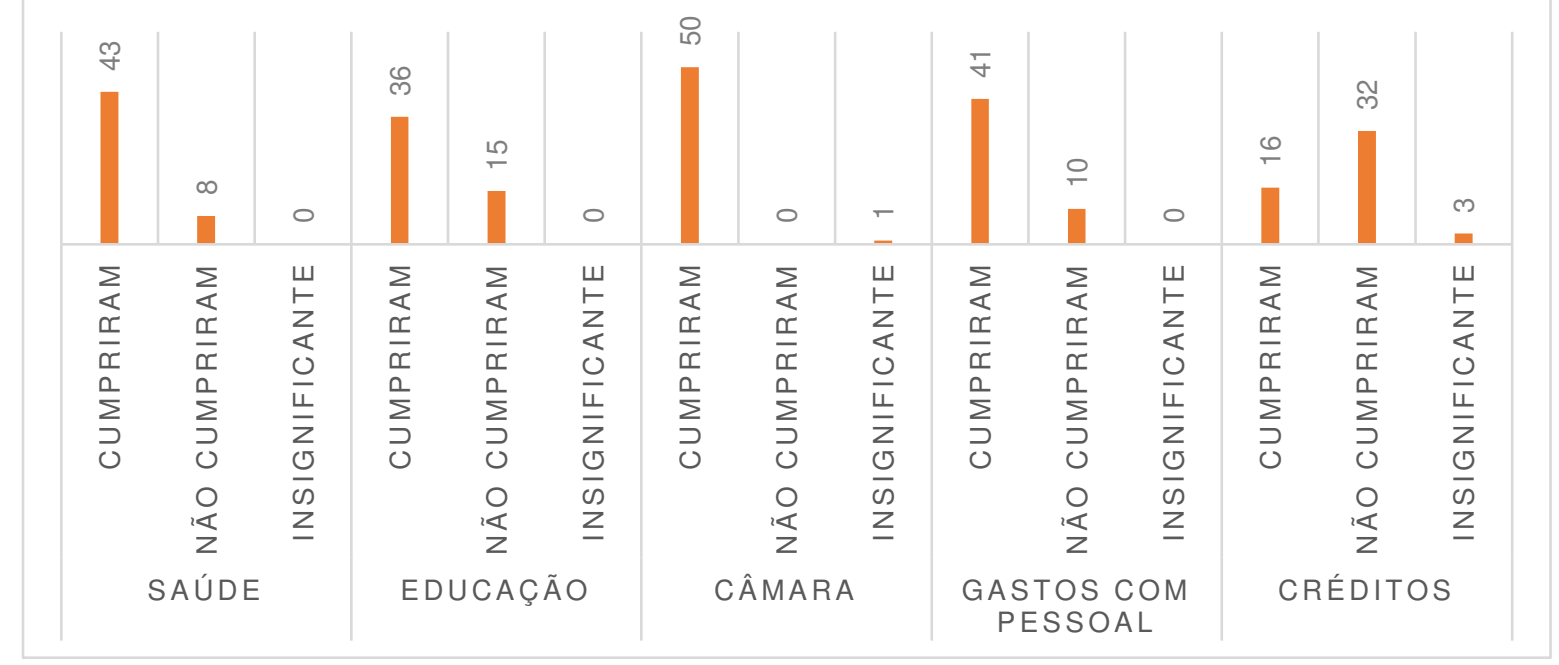

Fonte: dados da pesquisa

A maior rigidez com os mínimos constitucionais tem por objetivo melhorar os resultados de desenvolvimento dos municípios. Algumas evidências dessa relação foram encontradas por Leite Filho et al. (2015), cujos resultados identificaram que municípios que tiveram maior rigidez na gestão fiscal, em consonância com a LRF, obtiveram melhores resultados no desenvolvimento humano.

Por outro lado, analisando as rejeições por um único motivo, o não cumprimento da legislação quanto a aberturas de créditos foi o de maior ocorrência. Dos municípios que o fizeram, onze cometeram falhas com a prestação de contas, e sete prefeitos citados não apresentaram justificativas ao corpo técnico do TCEMG. 
Os 8 municípios que obtiveram aprovação das contas mesmo não cumprindo a exigência com abertura de créditos, conseguiram o parecer favorável porque o TCEMG considerou que as irregularidades apontadas não comprometeram a saúde fiscal dos municípios. De modo que o Tribunal apenas advertiu que no próximo exercício fossem atendidas as normativas relacionadas, para evitar que a repetição da ocorrência resultasse em rejeição das contas.

Ao todo, observou-se que 106 municípios tiveram algum problema com abertura de créditos no processo de prestação das contas públicas. Quatro deles abriram créditos suplementares que comprometeram o equilíbrio das contas públicas, os quais foram abertos sem recursos disponíveis em contas. A distribuição dos relatórios conforme limites legais e constitucionais pode ser vista na Tabela 3.

Tabela 3: Distribuição dos relatórios conforme os limites legais e constitucionais

\begin{tabular}{|c|c|c|c|c|c|c|c|c|c|}
\hline & & Rejeição & $\begin{array}{c}\% \\
\text { Rej. }\end{array}$ & $\begin{array}{c}\text { Com } \\
\text { ressalvas }\end{array}$ & $\% \mathrm{C} /$ res. & Aprovação & \% Apr. & Total & $\% \mathrm{~T}$. \\
\hline \multirow{3}{*}{$\begin{array}{l}\frac{0}{0} \\
\text { ஸ } \\
\text { ஸे }\end{array}$} & Cumpriram & 43 & 6,29 & 4 & 0,58 & 628 & 91,81 & 675 & 98,68 \\
\hline & Não cumpriram & 8 & 1,17 & 0 & 0,00 & 0 & 0,00 & 8 & 1,17 \\
\hline & Insignificante & 0 & 0,00 & 0 & 0,00 & 1 & 0,15 & 1 & 0,15 \\
\hline \multirow{3}{*}{ 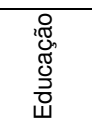 } & Cumpriram & 36 & 5,26 & 4 & 0,58 & 627 & 91,67 & 667 & 97,51 \\
\hline & Não cumpriram & 15 & 2,19 & 0 & 0,00 & 0 & 0,00 & 15 & 2,19 \\
\hline & Insignificante & 0 & 0,00 & 0 & 0,00 & 2 & 0,29 & 2 & 0,29 \\
\hline \multirow{3}{*}{ 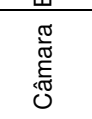 } & Cumpriram & 50 & 7,31 & 4 & 0,58 & 623 & 91,08 & 677 & 98,98 \\
\hline & Não cumpriram & 0 & 0,00 & 0 & 0,00 & 0 & 0,00 & 0 & 0,00 \\
\hline & Insignificante & 1 & 0,15 & 0 & 0,00 & 6 & 0,88 & 7 & 1,02 \\
\hline \multirow{3}{*}{ 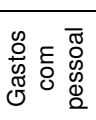 } & Cumpriram & 41 & 5,99 & 4 & 0,58 & 584 & 85,38 & 629 & 91,96 \\
\hline & Não cumpriram & 10 & 1,46 & 0 & 0,00 & 44 & 6,43 & 54 & 7,89 \\
\hline & Insignificante & 0 & 0,00 & 0 & 0,00 & 1 & 0,15 & 1 & 0,15 \\
\hline \multirow{3}{*}{ 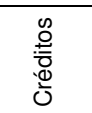 } & Cumpriram & 16 & 2,34 & 2 & 0,29 & 556 & 81,29 & 574 & 83,92 \\
\hline & Não cumpriram & 32 & 4,68 & 0 & 0,00 & 8 & 1,17 & 40 & 5,85 \\
\hline & Insignificante & 3 & 0,44 & 2 & 0,29 & 65 & 9,50 & 70 & 10,23 \\
\hline
\end{tabular}

Fonte: dados da pesquisa

Os princípios de insignificância, razoabilidade e proporcionalidade, embora apresentem conotações diferentes, assemelham-se o suficiente para possibilitar a aplicação de qualquer um deles em situações cujo descumprimento do dispositivo legal tenha ocorrido por diferenças mínimas, quase imperceptíveis, e com baixa capacidade de complicações nas contas públicas. Em especial são aplicados quando o descumprimento corresponde ao fato de se ultrapassar o limite de gastos com valores inferiores a $1 \%$ do total. Para fins desta pesquisa, o termo "insignificância" corresponde à aplicação dos três princípios.

Nesse sentido, nota-se que outros 65 municípios não cumpriram o limite de abertura de créditos estabelecido, mas obtiveram as contas aprovadas porque os valores em excesso foram considerados insignificantes. Outros três municípios se beneficiaram da aplicação do princípio de insignificância aos valores relacionados às aberturas de crédito, porém suas contas foram rejeitadas pelo não cumprimento do valor mínimo constitucional de investimento em saúde e/ou educação.

Tais resultados foram observados também por Laureano et al. (2017), que encontraram maior flexibilidade nos pareceres dos conselheiros. Contudo, os autores afirmam que, apesar do posicionamento dos conselheiros ao considerarem que tais descumprimentos não afetaram o equilíbrio financeiro, não há considerações na LRF sobre o ponto que pode ser tratado como desequilíbrio das finanças públicas (LAUREANO et al., 2017).

O não cumprimento do limite do repasse ao poder legislativo municipal, o qual é usualmente estipulado como 7\%, não ensejou motivo para categorizar a rejeição das contas. Quando o descumprimento aconteceu, os conselheiros aplicaram os princípios de insignificância, razoabilidade e/ou proporcionalidade para proceder à aprovação das contas.

Quanto aos gastos com pessoal, 44 municípios não cumpriram o limite estipulado, seja em relação ao limite total estipulado para o município $(60 \%)$ e/ou aquele relativo ao estabelecido para o poder executivo (54\%), ainda assim obtiveram suas contas aprovadas. Mesmo com o descumprimento averiguado em 2015, a decisão pela aprovação das contas desses municípios ocorreu devido à recondução dessas despesas para o teto da meta dentro do prazo estipulado pela LRF, que estabelece um período de dois quadrimestres para recondução das despesas. Ademais, em caso de o Produto Interno Bruto (PIB) do ano ser inferior a 1\%, como ocorreu no ano em análise, dobra-se o período para recondução das despesas, que passa para quatro quadrimestres (BRASIL, 2000). Dessa forma, apesar do não cumprimento no período de análise, os municípios conseguiram reconduzir suas contas no prazo determinado.

Apesar de os relatórios conterem um roteiro de apresentação, em que são verificadas as contas públicas dos municípios, diversos outros pontos foram destacados pelos técnicos, conselheiros e equipe do MP de contas. Observou-se, por exemplo, que 193 relatórios continham orientações acerca dos limites para abertura de créditos suplementares e adicionais, visto que os municípios referentes destinaram a esse fator 
valores superiores a $20 \%$. Essa destinação chamou a atenção dos analistas das contas, como se pode observar em um dos relatórios emitidos pelo Cons. 3, que a considera como uma:

[...]prática que se aproxima da concessão ilimitada de créditos, fazendo presumir a falta de planejamento e o desvirtuamento do orçamento-programa, pondo em risco- os objetivos e metas governamentais.

Insta ressaltar que essa ocorrência merece melhor atenção do gestor municipal, por ser indicativa de que o planejamento governamental foi pouco eficiente. O orçamento hoje é considerado importante e indispensável instrumento de planejamento e de implementação das ações governamentais. A concepção do orçamento-programa decorre de previsão contida na Constituição da República, que prescreve rigoroso sistema para atuação governamental, ao determinar que leis de iniciativa do Poder Executivo estabeleçam o plano plurianual, as diretrizes orçamentárias e os orçamentos anuais.

Em três municípios os limites não foram apontados pelos instrumentos legais que ditam o orçamento público, em outro município o limite estabelecido foi de $100 \%$, e outros quatros estabeleceram como limite o valor de $80 \%$ do total orçado.

Outro ponto de análise dos relatórios consiste em averiguar o cumprimento das metas estabelecidas para o Plano Nacional de Educação (PNE), com destaque para a primeira meta que estabelece, até 2016, o atendimento a $100 \%$ das crianças de quatro e cinco anos, na educação infantil, e $50 \%$ das crianças de até 3 anos, em creches. Ao todo, 536 municípios foram orientados para o cumprimento do PNE. Outras metas do plano também foram citadas, tais como a terceira, que se trata da universalização da educação para jovens de 15 a 17 anos, até o ano de 2016, e a nona meta, que estipula a elevação da alfabetização de pessoas com 15 anos ou mais, até o final de 2015 , para $93,5 \%$ da população.

Em dois municípios foram relatados, nos pareceres, divergências políticas entre o chefe do executivo e outros órgãos. Em Fronteira dos Vales, a divergência política ocorreu com o Instituto que administra o Regime Próprio de Previdência Social (RPPS), conforme apontou o relatório:

A defesa esclareceu que o excedente foi relativo às dotações do Instituto de Previdência do Município de Fronteira dos Vales - FONTPREV, tendo o Executivo enfrentado problemas com a contabilidade daquele Instituto que, por motivos políticos, atrasava a entrega dos documentos para consolidação e, também, não repassava os dados a este Tribunal em tempo hábil (Relatório município de Fronteira Dos Vales).

Após os técnicos e o relator do processo cruzarem as informações prestadas pelo RPPS do município, a irregularidade apresentada foi sanada. Já em São Gonçalo do Pará, o poder executivo manifestou que, por divergências políticas com o poder legislativo, havia dificuldades na aprovação de leis, entre elas as de autorização de abertura de créditos, o que causou a falha de abertura de créditos sem aparato legal. Essa justificativa, no entanto, não se mostrou suficiente para sanar a irregularidade detectada pelo órgão técnico,

No município de Carangola, os técnicos encontraram despesas excedentes realizadas pelo poder executivo. Na justificativa, o prefeito alegou que parte dessas despesas dizem respeito ao serviço municipal de saneamento básico e infraestrutura, de forma que as falhas cometidas não poderiam imputar responsabilidade a ele. Quanto a essa justificativa, o órgão técnico respondeu:

Quanto à alegação de que o defendente não poderia ser responsabilizado pela irregularidade apontada, o Orgão Técnico informou que a mesma é improcedente, uma vez que, o Prefeito Municipal é o representante político e jurídico do ente. Assim, ele é a parte legítima para responder pelas contas que apresenta e não o ente (Relatório município de Carangola).

Essas constatações encontradas durante o processo de análise realizado pelo TCEMG, ainda que façam parte de um parecer prévio, demonstram a necessidade de verificação de outros aspectos relacionados às diversas áreas da administração pública municipal, além daqueles que devem ser averiguados conforme demanda a legislação atual.

Nota-se que há desconhecimento e dificuldade do representante executivo em cumprir as exigências legais, não somente em relação às contas públicas. Ressalta-se ainda a existência de conflitos políticos que podem afetar o bom funcionamento da gestão, embora fosse exposta apenas por dois relatórios.

Percebe-se que, embora os resultados possam desempenhar importantes elementos de fiscalização e identificação de falhas, como dito por Rocha (2013), as análises presentes nos relatórios são pequenas, considerando todo o universo de gastos de recursos públicos. Por outro lado, minimizar essas informações pode ser uma atitude ingênua, dado o volume de situações descritas pelo órgão avaliador, cabendo ao analista buscar compreender os motivos de tais decisões.

\section{Considerações Finais}

A presente pesquisa teve por objetivo verificar os julgamentos das contas de governo dos municípios de Minas Gerais. Notou-se que os municípios mineiros possuem diversas dificuldades em cumprir normas relacionadas à abertura de créditos e à prestação de contas. Destacam-se ainda a dificuldade na inserção de dados no sistema informatizado e na identificação das fontes orçamentárias para alocação das contas públicas.

Essas falhas podem ser resultado da falta de atualização dos burocratas quanto aos procedimentos técnicos e legais propostos pela legislação orçamentária. A dificuldade em atender tais procedimentos, bem 
como a inexperiência e o desconhecimento por parte dos operadores, podem influenciar no aumento desses equívocos. Nesse caso, recomenda-se que a equipe técnica seja capacitada e treinada para executar tais ações, de forma a compreender os dispositivos legais, atualizar-se nos procedimentos e evitar a ocorrência desses erros.

Por esse motivo, e entendendo a limitação deste estudo em verificar os motivos de ocorrência das falhas, recomenda-se, para pesquisas futuras, uma análise da capacidade estatal, em especial no contexto da burocracia pública municipal, a fim de averiguar de que forma ela influencia a qualidade da gestão pública municipal.

Ao mesmo tempo em que houve um grande número de municípios cujas prestações de contas apresentaram falhas relacionadas aos créditos, os problemas com a abertura de contas se tornaram os principais motivos para rejeição das contas. Por vezes, os municípios não compreendiam como executar alguma despesa ou proceder à concessão de créditos; extrapolando valores concedidos e/ou não criando amparos legais para as concessões realizadas.

Ressalta-se ainda que os relatórios de parecer prévio de prestação de contas do executivo municipal são analisados por membros do órgão técnico, do Ministério Público de contas e pelos conselheiros do TCEMG, os quais por vezes apresentam decisões conflituosas; percebeu-se que o órgão técnico executou a avaliação das contas mais rigidamente. Por outro lado, os conselheiros do TCEMG foram mais parcimoniosos, aplicando os princípios de insignificância, razoabilidade e proporcionalidade, tendo em vista que algumas contas, embora não cumprissem os dispositivos legais, não representaram problemas para a saúde fiscal do município.

Embora a LRF tenha surgido para auxiliar no controle das contas públicas, passados quinze anos de sua promulgação, observou-se que ainda há municípios que não conseguem atender os normativos estabelecidos. Ressalta-se que muitas falhas cometidas no ano de 2015 poderiam não resultar na rejeição das contas públicas no ano, contudo, elas poderiam ser motivo de reprovação se cometidas no ano posterior, em 2016. Isso se deve ao fato de o ano de 2016 representar possivelmente o último da gestão, o que exige mais rigor no cumprimento das normas da gestão fiscal.

Observa-se ainda que, apesar das falhas cometidas no processo de prestação de contas, o cumprimento do limite mínimo constitucional com gastos na área da Saúde e da Educação foi o elemento que mais influenciou a aprovação ou rejeição das contas. Nesse contexto, os resultados reforçam também a necessidade de priorização dessas duas áreas, visto que, apesar das normas estabelecidas, inclusive as que penalizam os municípios nos casos de descumprimento, muitos ainda não alcançam os valores mínimos de alocação de recursos para esses dois tipos de serviço.

Para fins acadêmicos, os resultados auxiliam no avanço da literatura referente ao processo de avaliação das contas públicas e à accountability. Os achados complementam pesquisas já realizadas e formam base para novas pesquisas, contribuindo para a agenda de pesquisas sobre as análises das contas públicas. Nota-se que, apesar de os pareceres do TCEMG configurarem decisões sobre as contas públicas, seus relatórios não possuem efeitos imediatos sobre o gestor, servindo como suporte para verificação realizada pelo plenário das câmaras municipais, os quais podem acatar as decisões ou não. Nesse caso, embora exerça papel fiscalizador, as decisões do TCEMG muito se assemelham a recomendações para julgamentos. Assim, indica-se, para pesquisas futuras, uma análise das prestações de contas junto ao poder legislativo local, com vistas a compreender como são acolhidas as análises do Tribunal.

Ademais, as decisões tomadas pelo TCEMG tomam como base o cumprimento ou não da legislação, sem considerar os resultados alcançados com os recursos aplicados. Assim, seu foco está em cumprir limites de gastos, sem buscar garantias dos resultados desses gastos para o bem-estar social. Nesse sentido, sugere-se, para novos estudos, avaliar a relação do cumprimento da legislação fiscal com a melhoria das condições sociais.

Por fim, por considerar apenas um exercício fiscal, e tendo em vista que a publicação dos relatórios ocorreu anos após a ocorrência dos fatos, não foi possível neste estudo identificar se as recomendações realizadas foram cumpridas, o que fica como sugestão para pesquisas futuras.

\section{Referências}

ABRUCIO, F. L.; LOUREIRO, M. R. Finanças públicas, democracia e accountability: debate teórico e o caso brasileiro. In: BIDERMAN, C.; ARVATE, P. Economia do Setor Público no Brasil. Rio de Janeiro: Elsevier, 2004. p. 75-102.

ALESINA, A. F.; PEROTTI, R. Budget Deficits and Budget Institutions. In: POTERBA, J. M. Fiscal Institutions and Fiscal Performance. Chicago: University of Chicago Press, 1999. Cap. 1, p. 13-36.

ANDRADE, N. D. A.; FORTES, M. A Lei de Responsabilidade Fiscal nos Municípios, Uma Revisão Crítica. Reuna, Belo Horizonte, v. 10, n. 3, p. 53-73, setembro/dezembro 2005. 
ARANTES, R. B. et al. Controles democráticos sobre a administração pública no Brasil: Legislativo, tribunais de contas, Judiciário e Ministério Público. In: ABRUCIO, F. L.; LOUREIRO, M. R. G.; PACHECO, R. S. Burocracia e Política no BRASIL: desafios para o Estado democrático no século XXI. Rio de Janeiro: Editora FGV, 2010. Cap. 3, p. 109-147.

ARAÚJO, A. H. D. S.; SANTOS FILHO, J. E. D.; GOMES, F. G. Lei de Responsabilidade Fiscal: efeitos e consequências sobre os municípios alagoanos no período 2000-10. Revista de Administração Pública, Rio de Janeiro, v. 49, n. 2, p. 739-759, maio/jun. 2015. Disponivel em: <http://dx.doi.org/10.1590/00347612132652>. Acesso em: 17 jan. 2018.

BAIÃO, A. L.; CUNHA, A. S. M. D.; SOUZA, F. S. R. N. D. Papel das Transferências Intergovernamentais na Equalização Fiscal dos Municípios Brasileiros. Revista do Serviço Público, Brasília, v. 68, n. 3, p. 583-610, Jul./Set. 2017. Disponivel em: <https://doi.org/10.21874/rsp.v68i3.1406>. Acesso em: 2018 dez. 2018.

BRASIL. Lei no 4.320, de 17 de março de 1964. Brasília: Diário Oficial da União, 1964.

BRASIL. Constituição da República Federativa do Brasil. Brasília: Senado, 1988.

BRASIL.LEI COMPLEMENTAR № 101, DE 4 DE MAIO DE 2000. Diário Oficial da União, Brasília, maio 2000.

BRASIL. Lei no 12.527, de 25 de novembro de 2011. Diário Oficial da União, Poder Executivo, DF, p. Edição extra, nov. 2011.

CAMARGO, M. E.; SEHNEM, A. Efeitos da Lei de Responsabilidade Fiscal sobre a prestação de contas das prefeituras catarinenses. Revista de Administração, Contabilidade e Economia, v. 9, n. 1-2, p. 251-272, jan./dez. 2010. Disponivel em: <http://editora.unoesc.edu.br/index.php/race/article/view/614>. Acesso em: 28 ago 2018.

CELLARD, A. A análise documental. In: POUPART, J., et al. A pesquisa qualitativa: Enfoques epistemológicos e metodológicos. São Paulo: Editora Vozes, 2008. p. 295-316.

COSTA, G. P. C. L. D.; GARTNER, I. R. O efeito da função orçamentária alocativa na redução da desigualdade de renda no Brasil: uma análise dos gastos em educação e saúde no período de 1995 a 2012. Revista de Administração Pública, Rio de Janeiro, v. 51, n. 2, p. 264-293, mar./abr. 2017. Disponivel em: <http://dx.doi.org/10.1590/0034-7612155194>. Acesso em: 11 dez. 2018

CRUZ, C. F. D. Resonsabilidade na Gestão Fiscal: Um estudo em grandes municípios com base nos pilares da Lei de Responsabilidade Fiscal no período de 2010-2013. São Paulo: (Tese de Doutorado em Controladoria e Contabilidade) - Universidade de São Paulo, USP, 2015.

CRUZ, C. F. D.; AFONSO, L. E. Gestão fiscal e pilares da Lei de Responsabilidade Fiscal: evidências em grandes municípios. Revista de Administração Pública, Rio de Janeiro, v. 52, n. 1, p. 126-148, jan./fev. 2018. Disponivel em: <http://dx.doi.org/10.1590/0034-7612165847>. Acesso em: 28 ago 2018.

GERIGK, W.; CLEMENTE, A.; TAFFAREL, M. O IMPACTO DA LEI DE RESPONSABILIDADE FISCAL SOBRE A GESTÃO FINANCEIRA MUNICIPAL: um estudo com os municípios do Paraná. Revista Eletrônica de Ciência Administrativa (RECADM), Campo Largo, v. 10, n. 1, p. 64-83, 2011.

GIACOMONI, J. Orçamento Público. 15ª. ed. São Paulo: Atlas, 2010.

GRANT, R. W.; KEOHANE, R. O. Accountability and Abuses of Power in World Politics. The American Political Science Review, v. 99, n. 1, p. 29-43, fev. 2005. Disponivel em: <http://www.jstor.org/stable/30038917>. Acesso em: 13 fev. 2018.

IBGE. Banco de Dados Agregados. Instituto Brasileiro de Geografia e Estatística, n.d. Disponivel em: <http://www.sidra.ibge.gov.br/>. Acesso em: 14 out. 2015.

KRONBAUER, C. A. et al. Análise de inconsistências apontadas pelo TCE/RS em auditorias municipais: estudo do controle externo da gestão pública. Revista de Contabilidade e Organizações, Ribeirão Preto, v. 5, n. 12, p. 50-71, mai-ago 2011. Disponivel em: <https://doi.org/10.11606/rco.v5i12.34794>. Acesso em: 29 ago. 2018. 
LAUREANO, R. V. et al. Divergências entre o posicionamento dos auditores públicos e dos conselheiros do TCE-RS na análise da LRF. Advances in Scientific and Applied Accounting, São Paulo, v. 10, n. 1, p. 91-109, Jan. / Abr. 2017. Disponivel em: <http://dx.doi.org/10.14392/asaa.2017100106>. Acesso em: 29 ago. 2018.

LEITE FILHO, G. A. et al. Efeitos da Lei de Responsabilidade Fiscal nos Indicadores de Desenvolvimento e de Responsabilidade Social dos Municípios do Estado de Minas Gerais. Revista Mineira de Contabilidade, Belo Horizonte, v. 16, n. 2, p. 14-25, maio/ago. 2015. Disponivel em:

$<$ http://revista.crcmg.org.br/index.php?journal=rmc\&page $=$ article\&op=view\&path\%5B $\% 5 \mathrm{D}=74>$. Acesso em: 28 ago 2018.

LOUREIRO, M. R.; ABRUCIO, F. L. Política e Reformas Fiscais no Brasil Recente. Revista de Economia Política, v. 24, n. 1, p. 50-72, jan./mar. 2004. Disponivel em: <http://www.rep.org.br/PDF/93-5.PDF>. Acesso em: 17 jan. 2018.

LÜDKE, M.; ANDRÉ, M. E. D. A. Pesquisa em educação: abordagens qualitativas. São Paulo: EPU, 1986.

MACEDO, J. D. J.; CORBARI, E. C. Efeitos da Lei de Responsabilidade Fiscal no endividamento dos Municípios Brasileiros: uma análise de dados em painéis. Contabilidade \& Finanças, São Paulo, v. 20, n. 51, p. 44-60, setembro 2009.

MANIN, B.; PRZEWORSKI, A.; STOKES, S. C. Elections and Representation. In: PRZEWORSKI, A.; STOKES, S. C.; MANIN, B. Democracy, Accountability, and Representation. Cambridge: Cambridge University Press, 1999. p. 29-54. Acesso em: 18 set. 2018.

MARANHÃO, J. Origem dos Tribunais de Contas : evolução do Tribunal de Contas no Brasil. Revista de informação legislativa, v. 29, n. 113, p. 327-330, jan./mar. 1992. Disponivel em:

<http://www2.senado.leg.br/bdsf/handle/id/175976>. Acesso em: 29 ago. 2018.

MINAS GERAIS. Lei Complementar 102, de 17 de Janeiro de 2008. [S.I.]. 2008.

MINAS GERAIS. Instrução Normativa no 02/2015. Belo Horizonte. 2015.

MINAS GERAIS. Secretaria de estado de Fazenda de Minas Gerais. Relatório resumido da execução orçamentária. SEF. Belo Horizonte. 2018.

MUSGRAVE, R. A. The Theory of Public Finance: a study in public economy. New York: McGraw-Hill, 1959.

MYRDAL, G. Economic Theory and Underdeveloped Region. Londres: Methuen, 1963.

O'DONNELL, G. Delegative democracy? Journal of democracy, v. 5, n. 1, p. 55-69, Jan. 1994. Disponivel em: <https://muse.jhu.edu/article/225426/summary>. Acesso em: 13 fev. 2018.

O'DONNELL, G. Horizontal Accountability: The Legal Institutionalization of Mistrust. In: SCOTT

MAINWARING, C. W. Democratic Accountability in Latin America. New York: Oxford University Press, 2003. Cap. 2, p. 34 - 54.

PAIVA, J. M. et al. ANÁLISE NORMATIVA DA TRANSPARÊNCIA EM UM TRIBUNAL DE CONTAS DOS MUNICÍPIOS. AOS - Amazônia, Organizações e Sustentabilidade, v. 4, n. 2, p. 173-188, julho/dezembro 2015.

PEREIRA, J. R. T.; CORDEIRO FILHO, J. B. Rejeições de Prestação de Contas de Governos Municipais: O que está acontecendo? Contabilidade Gestão e Governança, v. 15, n. 1, p. 33-43, jan./abr. 2012.

Disponivel em: <https://cgg-amg.unb.br/index.php/contabil/article/view/393>. Acesso em: 28 ago 2018.

REIS, A. F. D.; DACORSO, A. L. R.; TENÓRIO, F. A. G. Influência do uso de tecnologias de informação e comunicação na prestação de contas públicas municipais - um estudo de caso no Tribunal de Contas dos Municípios do estado da Bahia. Revista de Administração Pública, Rio de Janeiro, v. 49, n. 1, p. 231-251, jan./fev. 2015. Disponivel em: <http://dx.doi.org/10.1590/0034-76121664>. Acesso em: 29 ago. 2018. 
ROCHA, A. C. A realização da accountability em pareceres prévios do Tribunal de Contas de Santa Catarina. Revista de Administração Pública, Rio de Janeiro, v. 47, n. 4, p. 901-25, jul./ago. 2013.

Disponivel em: <http://bibliotecadigital.fgv.br/ojs/index.php/rap/article/view/9638>. Acesso em: 29 ago 2018.

ROCHA, D. G. D.; ZUCCOLOTTO, R. A Modernização dos Tribunais de Contas do Brasil: Avaliação da Implantação do PROMOEX nos Tribunais de Contas Subnacionais. Enfoque: Reflexão Contábil, Maringá, v. 36, n. 3, p. 70-88, set./dez. 2017. Disponivel em: <http://dx.doi.org/10.4025/enfoque.v36i3.32160 >. Acesso em: 12 jan. 2018.

SCHEDLER, A. Conceptualizing Accountability. In: SCHEDLER, A.; DIAMOND, L. J.; PLATTNER, M. F. The Self-restraining State: Power and Accountability in New Democracies. Boulder, CO: Lynne Rienner Publisers Inc., 1999. p. 13 - 28.

SÖTHE, A.; SÖTHE, V.; GUBIANI, C. A. O impacto da Lei de Responsabilidade Fiscal: uma análise do desempenho das contas públicas municipais do estado do Rio Grande do Sul. Revista do Serviço Público Brasília, Brasília, v. 63, n. 2, p. 177-197, abr/jun 2012. Disponivel em: $<$ https://doi.org/10.21874/rsp.v63i2.94>. Acesso em: 28 ago 2018.

VIEIRA, J. B. Estado, sociedade civil e Accountability. Ensaios FEE, Porto Alegre, v. 26, n. 1, p. 605-626, jun. 2005. Disponivel em: <https://revistas.fee.tche.br/index.php/ensaios/article/view/2095>. Acesso em: 18 set. 2018.

\section{NOTAS}

\section{AGRADECIMENTOS}

O presente trabalho foi realizado com apoio da Coordenação de Aperfeiçoamento de Pessoal de Nível Superior - Brasil (CAPES) - Código de Financiamento 001. Agradecemos ao TCE-MG pela disponibilidade dos dados.

\section{CONTRIBUIÇÃO DE AUTORIA}

Concepção e elaboração do manuscrito: W. A. Mendes, L. P. Rocha, M. A. M. Ferreira, E. R. Faria.

Coleta de dados: W. A. Mendes, L. P. Rocha

Análise de dados: W. A. Mendes

Discussão dos resultados: W. A. Mendes, L. P. Rocha, M. A. M. Ferreira, E. R. Faria

Revisão e aprovação: W. A. Mendes, L. P. Rocha, M. A. M. Ferreira, E. R. Faria

\section{CONJUNTO DE DADOS DE PESQUISA}

O conjunto de dados que dá suporte aos resultados deste estudo não está disponível publicamente.

\section{FINANCIAMENTO}

O presente trabalho foi realizado com apoio da Coordenação de Aperfeiçoamento de Pessoal de Nível Superior - Brasil (CAPES) - Código de Financiamento 001

\section{CONSENTIMENTO DE USO DE IMAGEM}

Não se aplica.

\section{APROVAÇÃO DE COMITÊ DE ÉTICA EM PESQUISA}

Não se aplica.

\section{CONFLITO DE INTERESSES}

Não se aplica.

\section{LICENÇA DE USO}

Os Direitos Autorais para artigos publicados neste periódico são do autor, com direitos de primeira publicação para a Revista. Em virtude de aparecerem nesta Revista de acesso público, os artigos são de uso gratuito, com atribuições próprias, em aplicações educacionais, de exercício profissional e para gestão pública. A Revista adotou a licença Creative Commons Atribuição 4.0 Internacional - CC BY NC ND. Esta licença permite acessar, baixar (download), copiar, imprimir, compartilhar, reutilizar e distribuir os artigos desde que com a citação da fonte, atribuindo os devidos créditos de autoria. Nesses casos, nenhuma permissão é necessária por parte dos autores ou dos editores. Autores têm autorização para assumir contratos adicionais separadamente, para distribuição não-exclusiva da versão do trabalho publicada nesta revista (ex.: publicar em repositório institucional ou um capítulo de livro).

\section{PUBLISHER}

Universidade Federal de Santa Catarina. Curso de Ciências Contábeis e Programa de Pós-graduação em 
Contabilidade. Publicação no Portal de Periódicos UFSC. As ideias expressadas neste artigo são de responsabilidade de seus autores, não representando, necessariamente, a opinião dos editores ou da universidade.

\section{EDITORES}

Carlos Eduardo Facin Lavarda e Suliani Rover

\section{HISTÓRICO}

Recebido em: 25/04/2019 - Revisado por pares em: 04/10/2019 - Reformulado em: 11/04/2020 Recomendado para publicação em: 02/05/2020 - Publicado em: 30/05/2020 